\title{
Comparison Of Acetic Acid With As Formiic Acid Latex Pump Material
}

\author{
Rudi Munzirwan Siregar \\ Chemistry Department, Faculty of Mathematics and Sciences, Medan State University, Medan 20221, Indonesia \\ Email : rudimunzirwan@yahoo.com
}

\begin{abstract}
Research on the comparison of acetic acid and formic acid as a latex coagulant has been carried out. To the latex coconut shell charcoal (particle size 80 mesh) was added to the weight of 42 grams then the latex was coagulated with acetic acid and formic acid with a pH of 4.7. As a research, the quality of rubber was carried out by measuring the initial plasticity, plasticity retention index and viscosity of rubber mooney. Finally, latex coagulated with acetic acid produced a better rubber than latex coagulated with formic aci).
\end{abstract}

Keywords: Latex, Acetic Acid, Formic Acid, Coconut Shell Charcoal

\section{Pendahuluan}

Pada proses pengolahan karet terdapat tahapan penggumpalan lateks. Penggumpalan lateks dapat terjadi karena rusaknya kemantapan sistem koloid lateks. Kerusakan ini dapat terjadi dengan jalan penetralan muatan protein dengan penambahan asam sehingga muatan negatif dan muatan positif lateks setimbang ( $\mathrm{pH} 4,7$ ). Bahan kimia yang biasa digunakan dalam penggumpalan lateks adalah asam formiat. Asam ini dapat digunakan untuk menghambat terjadinya reaksi pengerasan pada karet selama penyimpanan (Nelteresia, 2018).

ilain pihak asam asetat dapat digunakan sebagai bahan penggumpal lateks. Asam ini juga dapat memperbaiki kekerasan karet (Anna, 2019). Dengan demikian lateks yang digumpalkan dengan asam asetat dan asam formiat diharapkan dapat memperbesar volume dari karet dan memperbaiki kekerasan karetnya sehingga mutu karetnya lebih baik (Haradi, 2017). Berdasarkan hal tersebut, penulis ingin membandingkan asam asetat dengan asam formiat sebagai bahan penggumpal lateks

\section{Metodologi Penelitian}

\subsection{Alat dan Bahan}

Alat yang digunakan dalam penelitian ini adalah Blanding mill, Lab mill, Wallace punch, Wallace plastimeter, Mooney Viscosimeter, Creper, Neraca analitis, Termometer, Stopwatch, Pembakar listrik, Oven, Desikator, dan Muffle Furnace.

Bahan yang digunakan adalah Lateks, Asam asetat, Arang yang diayak dengan ukuran 80 mesh, dan kertas lakmus indikator).

\subsection{Prosedur penelitian}

2.2.1.Pembuatan Arang dari Tempurung Kelaoa

Sebanyak 2 buah tempurung kelapa dibersihkan, dijemur di bawah sinar matahari, dan dipotong menjadi ukuran yang lebih kecil lalu dimasukkan ke dalam cawan porselin dan ditutup dengan aluminium foil. Selanjutnya dimasukkan ke dalam tanur pada suhu $500{ }^{0} \mathrm{C}$ selama 4 jam, lalu didinginkan dalam desikator dan dicuci dengan akuades. Arang yang terbentuk diovenkan pada 
suhu $100-105^{\circ} \mathrm{C}$, lalu didinginkan dalam desikator dan diayak dengan ayakan 80 mesh

\subsubsection{Asam asetat sebagai penggumpal lateks dengan bahan pengisi arang}

Disediakan lateks sebanyak 4 liter. Lateks kebun disaring dengan saringan 40 mesh untuk menghilangkan kotoran-kotoran yang terikut pada waktu penyadapan. Masing- masing 1 liter lateks dimasukkan kedalam mangkuk penggumpal, untuk mangkuk 1; 1 liter lateks ditambahkan arang yang ukuran partikelnya 80 mesh sebanyak 42 gram, lalu ditambahkan sedikit demi sedikit asam asetat sampai $\mathrm{pH} 4,7$; volume asam asetat saat $\mathrm{pH} 4,7$ adalah $20 \mathrm{ml}$. Perlakuan diatas diulangi dua kali perlakuan. Masing-masing koagulum karet yang terbentuk ditambahkan air secukupnya untuk menutupi permukaan koagulum tersebut, kemudian didiamkan selama satu malam. Selanjutnya masing-masing koagulum digiling dengan alat creper sebanyak sembilan kali gilingan dan diovenkan pada suhu $110{ }^{0} \mathrm{C}$ selama tiga setengah jam sehingga menghasilkan karet yang kering. Setelah itu masing-masing koagulum karet yang sudah kering digiling dengan alat lab mill sebanyak enam kali. Karet kering yang dihasilkan diuji mutu karetnya sesuai dengan ketentuan standard Indonesian rubber.

\subsubsection{Penetapan Nilai Plastisitas Awal Dan} Plastisitas Retensi Indeks (Kartowardoyo, 2015)

Ditimbang sekitar 25 gram karet yang sudah dikeringkan, lalu digiling dengan gilingan laboratorium sebanyak tiga kali dengan ketebalan antara 1,6-1,8 mm. Lembaran karet tersebut dilipat dua, ditekan perlahan-lahan dengan telapak tangan sehingga mempunyai ketebalan 3,3-3,6 $\mathrm{mm}$. Kemudian lembaran karet tersebut dipotong dengan alat Wallace punch sebanyak enam buah potongan uji dengan diameter $13 \mathrm{~mm}$. Untuk pengukuran plastisitas awal diambil potongan uji (1), sedangkan potongan uji (2) untuk pengukuran plastisitas setelah pengusangan. Potongan uji harus mempunyai ketebalan antara 3,2- 3,6 mm (ketelitian 0,01 mm) dengan garis tengah 1,3 mm. Diletakkan potongan uji (2) untuk pengukuran plastisitas setelah pengusangan diatas baki dan dimasukkan kedalam oven pada suhu $140^{\circ} \mathrm{C}$ selama 30 menit. Lalu dikeluarkan kemudian didinginkan sampai suhu kamar. Sementara potongan uji (1) sebanyak tiga buah diletakkan satu persatu diantara dua lembar kertas sigaret TST yang berukuran 35 $\mathrm{mm}$ x $45 \mathrm{~mm}$ selanjutnya diletakkan di atas piringan plastimeter lalu piringan plastimeter tersebut ditutup. Setelah ketukan pertama piringan bawah plastimeter akan bergerak ke atas selama 15 detik dan menekan piringan atas. Dilanjutkan sampai ketukan kedua berakhir yang ditandai dengan angka jarum mikrometer berhenti bergerak pada nilai plastisitas karet. Sedangkan potongan uji (2) setelah pengusangan tadi diukur dengan cara yang sama. Tiga potongan uji dari setiap contoh diambil angka rata- ratanya dan dibulatkan. Nilai plastisitas retensi indeks (PRI) dinyatakan dalam persen dengan rumus sebagai berikut:

$$
\begin{aligned}
& P R I=\frac{P a \times 100 \%}{P o} \\
& P a=\text { Plastisitas Setelah pengusangan } \\
& P o=\text { Plastisitas Sebelum Pengusangan }
\end{aligned}
$$

\subsubsection{Pengujian Viskositas Money (Subramaniam, 2016)}

Sebelum pengukuran dilakukan, alat viskosimeter terlebih dahulu dipanaskan selama satu jam. Masing-masing lembaran contoh karet diambil 2 buah potongan uji dengan menggunakan alat Wallace punch sehingga ukuran diameternya sama dengan ukuran diameter rotor. Ditusukkan rotor ke contoh karet pertama yang telah diberi lubang dengan gunting. Contoh kedua diletakkan tepat di atas rotor lalu dimasukkan bersama ke stator bawah. Ditutup stator atas dan setelah tertutup stopwatch dihidupkan. Setelah tepat satu menit, dijalankan rotor. Nilai viskositas dibaca dengan alat penunjuk. Angka yang ditunjukkan jarum mikrometer setelah menit keempat adalah nilai viskositas karet.

\section{Hasil dan Pembahasan}

\subsection{Hasil Analisis Plastisitas Awal (Po)}

Plastisitas awal adalah plastisitas karet mentah yang langsung diuji tanpa perlakuan khusus sebelumnya, yang ditentukan dengan alat Wallace plastimeter. Karet yang mempunyai plastisitas awal tinggi, mempunyai rantai molekul yang tahan terhadap oksidasi, sedangkan yang mempunyai plastisitas awal rendah mudah teroksidasi menjadi karet lunak (Honggokusumo, 2018). Hasil plastisitas awal (Po) karet dengan penggumpal asam asetat dapat dilihat pada Tabel 1 
Tabel 1. Hasil plastisitas awal (Po) karet dengan penggumpal asam asetat dan asam formiat.

\begin{tabular}{lllllll}
\hline Perlakuan & $\begin{array}{l}\text { Plastisitas } \\
\text { karet } \\
\text { formiat (\%) }\end{array}$ & $\begin{array}{l}\text { awal } \\
\text { asam }\end{array}$ & $\begin{array}{l}\text { Plastisitas } \\
\text { karet } \\
\text { asetat (\%) }\end{array}$ & $\begin{array}{l}\text { awal } \\
\text { asam }\end{array}$ \\
\cline { 2 - 7 } & 1 & 2 & $\begin{array}{l}\text { Rata- } \\
\text { rata }\end{array}$ & 1 & 2 & $\begin{array}{l}\text { Rata- } \\
\text { rata }\end{array}$ \\
\hline $\begin{array}{l}\text { 42 gram } \\
\text { arang }\end{array}$ & 46 & 45 & 45.5 & 49 & 48 & 48.5 \\
\hline
\end{tabular}

Dari Tabel 1 diatas menunjukkan bahwa latek yang digumpalkan dengan asam asetat menghasilkan nilai plastisitas awal yang lebih tinggi bila dibandingkan dengan lateks yang digumpalkan dengan asam formiat. Hal ini berarti dengan penambahan asam asetat menyebabkan logam dan zat-zat pengotor yang terdapat pada lateks berkurang pada waktu penggumpalan, sehingga nilai plastisitas awal karet yang dihasilkan tinggi, dan mutunya lebih baik (Nelteresia, 2018)

\subsection{Analisis Plastisitas Retensi Indeks (PRI)}

Nilai plastisitas Retensi indeks adalah suatu ukuran ketahanan karet terhadap pengusangan atau oksidasi pada suhu tinggi (Budiman 2017). Hasil plastisitas retensi indeks (PRI) karet dengan penggumpal asam asetat dan asam formiat dapat dilihat pada Tabel 2

Tabel 2. Plastisitas Retensi Indeks Karet dengan Penggumpal Asam Asetat dan Asam formiat

\begin{tabular}{|c|c|c|c|}
\hline \multirow[t]{3}{*}{ Perlakuan } & $\begin{array}{l}\text { Nilai } \mathbf{P l} \\
\text { retensi } \\
\text { indeks }(\mathrm{P})\end{array}$ & tisitas & \multirow[t]{2}{*}{$\begin{array}{l}\text { Nilai Plastisitas } \\
\text { Retensi indeks } \\
\text { asam asetat }(\%)\end{array}$} \\
\hline & $\begin{array}{l}\text { asam } \\
(\%)\end{array}$ & prmiat & \\
\hline & 2 & $\begin{array}{l}\text { Rata- } \\
\text { rata }\end{array}$ & $\begin{array}{l}\text { Rata- } \\
\text { rata }\end{array}$ \\
\hline $\begin{array}{l}42 \text { gram } \\
\text { arang }\end{array}$ & 80 & 80.5 & 84 \\
\hline
\end{tabular}

\subsection{Hasil Analisis Viskositas Mooney}

Viskositas karet mentah dinyatakan sebagai viskositas mooney, yang menunjukkan panjangnya rantai molekul, berat molekul, dan derajat pengikatan silang rantai molekulnya. Jika nilai viskositas tinggi berarti karet keras sehingga mutu karet yang dihasilkan tinggi (Subramaniam, 2016).
Hasil Viskositas Mooney dengan penggumpal asam asetat dan asam formiat dapat dilihat pada Tabel 2 .

Tabel 3. Viskositas Mooney Karet dengan penggumpal Asam Aseat dan Asam Formiat

Perla Nilai viskositas Nilai viskositas

kuan mooney asam mooney asam

\begin{tabular}{lllllll} 
& \multicolumn{2}{c}{ asetat $(\%)$} & & \multicolumn{3}{c}{ formiat $(\%)$} \\
\cline { 2 - 7 } & 1 & 2 & $\begin{array}{l}\text { Rata- } \\
\text { rata }\end{array}$ & 1 & 2 & $\begin{array}{l}\text { Rata- } \\
\text { rata }\end{array}$ \\
\hline $\begin{array}{l}42 \text { gram } \\
\text { arang }\end{array}$ & 77 & 78 & 77,5 & 76 & 76 & 76 \\
\hline
\end{tabular}

Dari Tabel 3 menunjukkan bahwa lateks yang digumpalkan dengan asam asetat menghasilkan nilai viskositas mooney yang lebih tinggi bila dibandingkan dengan lateks yang digumpalkan dengan asam formiat, karena dengan penambahan penggumpal asam asetat, maka kandungan senyawa bukan karet yang berfungsi sebagai katalis pembentuk ikatan silang terlarut dalam fase serum, sehingga karet yang dihasilkan keras dan mempunyai ketahanan yang tinggi terhadap gesekan bila dibandingkan dengan lateks yang digumpalkan dengan asam Formiat (Lim, 1989IV.

\section{IV.KESIMPULAN}

Dari hasil penelitian yang telah dilakukan dapat disimpulkan bahwa lateks yang digumpalkan dengan asam asetat menghasilkan mutu karet yang lebih baik dibandingkan dengan lateks yang digumpalkan dengan asam formiat, karena nilai platisitas awal, plastisitas retensi indeks dan viskositas money karet yang digumpalkan dengan asam asetat lebih tinggi dibandingkan dengan dengan asam formiat

\section{DAFTAR PUSTAKA}

1. Anna. H. M. 2019. Pemanfaatan Arang Cangkang Kemiri dan Arang Aktif Cangkang Kemiri Untuk Menyerap Logam Krom dengan spektrofotometri Serapan Atom". Skripsi Jurusan Kimia, FMIPA USU.

2. Budiman S. 2017. Rencana Perbaikan Pengolahan Karet Rakyat Dalam Perbaikan Mutu Ekspor, Kelompok teknologi pengolahan hasil pusat penelitian perkebunan sungai putih 
3. Haradi B. 2017. Usaha Perbaikan Mutu Bahan Olah Karet. Direktorat Jendral Perkebunan.

4. Hanggokusumo S. 2018. Permintaan konsumen mengenai spesifikasi SIR, warta perkaretan volume 3 .

5. Kartowardoyo S. 2015. Penggunaan wallace Plastimeter untuk penentuan karakter pematangan karet alam, UGM yogyakarta.

6. Nelteresia. 2018. Pemanfaatan destilat limbah cair kakao sebagai penggumpal lateks, Skripsi jurusan kimia universitas sumatera utara.

7. Soewarti. 2016. Pengaruh arang dan $\mathrm{PH}$ terhadap lateks kebun dengan sifat karet yang diperoleh, Menara perkebunan, volume 3.

8. Subramaniam. 2017. Viskositas mooney raw material rubber research institute 